\title{
A comparative histopathological evaluation of acute toxicities associated with Scillaren-A, corn cob powder and their combinations in rats
}

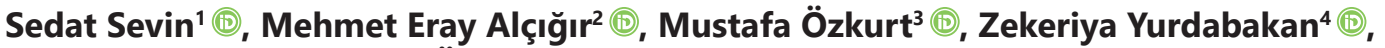 \\ Ömer Yalçın 5 (0), Ender Yarsan' ${ }^{6}$ (]) \\ 1,6 Ankara University, Veterinary Faculty, Department of Pharmacology and Toxicology, Ankara, Turkey. \\ ${ }^{2}$ Kirikkale University, Veterinary Faculty, Department of Pathology, Kirikkale, Turkey. \\ 3,5 Almer Pharmaceutical Food, Agriculture, Livestock, Veterinary, Consultancy, Industry Trade Limited Company, Ankara, Turkey. \\ ${ }^{4}$ Kahramanmaraş Sütçü Imam University, Faculty of Agriculture, Department of Zootechnics, Kahramanmaraş, Turkey.
}

Geliş Tarihi / Received: 29.12.2021, Kabul Tarihi / Accepted: 19.01.2022

\begin{abstract}
The purpose of the study was to comparatively evaluate the efficacy of Scillaren-A in rats. A total of 32 female Wistar albino rats were used to develop acute toxicity for $48 \mathrm{~h}$. The rats were randomly divided into four groups including $n=8$ / each group (G.I-G.IV). Toxicity groups (G.I, G.II, and G.III) and control group (G.IV) were established. The experimental groups were intoxicated with scillaren A, corn cob powder, and their combinations, respectively. The rats in the control group were remained intoxicated and fed with standard pellets. The experiment was ended 48 hours after the intoxication. Histopathological findings in vital organs (liver, kidney, lung, heart, brain) and then other organs (intestine, spleen) were evaluated. Tissues were fixed in $10 \%$ buffered formalin $(\mathrm{pH}=7.2)$ and embedded in paraffin. The histopathologic findings were evaluated on the standard $\mathrm{H} \& \mathrm{E}$ stained sections. The major histopathological changes, vascular changes including hyperemia and haemorrhagia, alterative changes including degeneration and necrosis, inflammation, some regenerative and reparative changes including hyperplasia and fibrosis in organs were scored. It is believed that both formulations can be effective on death later on, be utilized as a rodenticide without environmental toxic effect, and be consumed rapidly by rats due to their attractive chemical traits.
\end{abstract}

Keywords: Corn cob powder, histopathology, intoxication, rat, Scillaren-A

\section{Ratlarda Scillaren-A, mısır koçanı tozu ve kombinasyonları ile ilişkili akut toksisitelerin karşılaştırmalı histopatolojik değerlendirilmesi}

\begin{abstract}
Özet: Çalışmanın amacı Scillaren-A'nın ratlarda etkinliğini karşılaştırmalı olarak değerlendirmekti. Kırk sekiz saat boyunca akut toksisite geliştirmk için toplam 32 dişi Wistar albino rat kullanıldı. Ratlar rastgele dört gruba ayrıldı (her grupta n=8 / G.I-G.IV). Toksisite grupları (G.I, G.II ve G.III) ve kontrol grubu (G.IV) oluşturuldu. Deney grupları sırasıyla scillaren A, mısır koçanı tozu ve bunların kombinasyonu ile zehirlendi. Kontrol grubundaki ratlar zehirlenmedi ve standart peletler ile beslendi. Toksikasyondan 48 saat sonra deney sonlandııldı. Yaşamsal organlarda (karaciğer, böbrek, akciğer, kalp, beyin) ve ardından diğer organlarda (bağırsak, dalak) histopatolojik bulgular değerlendirildi. Dokular \%10'luk tamponlu formalin $(\mathrm{pH}=7.2)$ içinde tespit edildi ve parafine gömüldü. Histopatolojik bulgular standart H\&E boyalı kesitlerde değerlendirildi. Organlardaki önemli histopatolojik değişiklikler, hiperemi ve hemorajiyi içeren vasküler değişiklikler, dejenerasyon ve nekrozu içeren alteratif değişiklikler, yangı, hiperplazi ve fibrozis gibi bazı rejeneratif ve reperatif değişiklikler skorlandı. Her iki formülasyonun da ilerleyen zamanda ölüm gelişmesinde etkili olabileceğine, çevresel toksik etkisi olmaksızın bir rodentisit olarak kullanılabileceğine ve çekici kimyasal özellikleri nedeniyle ratlar tarafından hızla tüketilebileceğine inanılmaktadır.
\end{abstract}

Anahtar kelimeler: Histopatoloji, mısır koçanı tozu, rat, Scillaren-A, toksikasyon

\section{Introduction}

Medicinal plants have been used to cure health disorders and to prevent diseases (Aktaş et al. 2020). They have been shown to exert various biological activities including anti-cancer (Bilir et al. 2018; Alp et al. 2019), antimicrobial (Keyvan et al. 2019), an- tifungal (Mahlo et al. 2016), antiparasitic (Tutun et al. 2019), antioxidant (Kasote et al. 2015), and antihyperlipidemic (Sikarwar et al. 2014) properties. Today, various products are used to combat rodents. These products are mostly chemical, but there are also vegetable-based ones. For this purpose, one 
of the most widely used products nationally and internationally is the products obtained from corn cob powder. The rodenticidal activity of corn cob powder has been studied on both rats and mice and found useful in different countries on an international scale (Perry 2013; Jacob and Buckle 2018).

Urginea (Scilla) Maritima or squill, which is also known as sea onion, is located in the coastal Mediterranean area. It is obtained in powder form from the Liliaceae plant Urginea (Scilla) Maritima. It is an onion-like plant. Squill bulb extracts and dried powders have been used for the control of rodents since the 13th century. Although red squill has many alkaloids, scilliroside is the most toxic among others which provides rodenticidal activity. In particular, its bulbs have an anticoagulant activity and this chemical has a characteristic place among modern anticoagulant rodenticides (Gentry 1987; Gupta 2018). Some glycoside substances in squill bulbs; proscillaridin A, scillaren A, scilliroside, gammabufotalin, and scillirosidin were extracted. Among them, scilliroside toxicity is the most effective compared to others (Verbiscar et al. 1986a; Verbiscar et al. 1987b). For example, intake of Urginea (Scilla) Maritima at high doses or for a prolonged period is cardiotoxic or emetic. Scilliroside is inefficiently absorbed from the gastrointestinal tract and any remaining amount can be excreted via the urine. Due to a highly toxic bufadienolide glycoside, the red squill bulb can also cause a central nervous system failure. Thus, it causes convulsions and death as well as cardiovascular collapse (Tobyn et al. 2010).

Unfortunately, there are limited experimental studies regarding squilla glycosides, even though their active compounds have been well documented in numerous sources. According to the literature, Scillaren-A toxicants, red squill powder can contain up to $28 \%$ scilliroside, and baits usually have 0.01 $0.7 \%$ of the toxicant (Gratz 1973). In an experimental study, approximately $0.8 \mathrm{mg} / \mathrm{kg}$ LD50 dosage of Scilliroside was found lethal (Brooks and Htun 1980). Another experimental study reported that the oral LD50 of Scilliroside was $0.7 \mathrm{mg} / \mathrm{kg}$ in male rats, $0.43 \mathrm{mg} / \mathrm{kg}$ in female rats, and $0.35 \mathrm{mg} / \mathrm{kg}$ in mice (Bayazit and Konar 2010). Thus, Scillaren-A is a highly toxic chemical and is used effectively against Norway rats, black rats, house mice, long-tailed field mice, and field voles (The Pestisit Manual 1983).

The product to be prepared as a part of the study will be composed of corn cob powder and active ingredients obtained from the squill plant to support it. One of the most important disadvantages of corn cob powder used as a rodenticide is its high effectivity dose which provides active struggle with rodents. The priority approach that reveals the originality of the study starts at this point. The mechanism of action of neither corn cob powder nor squill glycosides for rats and mice has been fully elucidated. Various opinions were put forward and got accepted. In this study, the purpose was to comparatively evaluate the toxicity efficacy of Scillaren-A in rats. Thus, effective doses on the vital organs and the efficiency of different created formulations have been evaluated individually and collectively. It is believed that this study is the first comparative documentation on this topic based on literature knowledge.

\section{Material and Method}

\section{Plant Material and Preparation of Ethanol Extract}

U. Maritima (L.) Baker is grown mostly in the Aegean and Mediterranean regions of Turkey (Tanker and Tosun 1979). The leaves and tubers of U. Maritima (L.) Baker were collected from nature in Demirciler (Antalya, Manavgat, Turkey; Lat/Long 36.791924; 31.509417 ) in 2019 and cleaned from residual composts. The tubers were used directly in the extraction process after the bulbs are cut and finely crushed in the grinding machine (Spice Herb Grinder IC-25B).

Urginea Maritima (L.) Baker plant's tubers were ground mechanically with a machine (YOKEŞ, VBR-6000, Multi-Purpose Disperser). Following the grinding process, $2.4 \mathrm{~kg}$ for every $4 \mathrm{~kg}$ tubers were added to the scilla paste. Urginea Maritima (L.) Baker - magnesium sulfate paste was further diluted by 15 $L$ of Ethanol (Merck) and blended by a high-speed blender with a maceration derivative system. To ensure total extraction, the paste was washed with $5 \mathrm{~L}$ of Ethanol before sieving. The added Ethanol (Merck) was evaporated by a Rotary evaporator and $1000 \mathrm{ml}$ of the concentrated sample was obtained. The concentrated paste was coagulated by lead acetate at $\mathrm{pH}$ values below 6.8 and the existing lead acetate was absorbed by $10 \%$ sodium sulfate, and sieved again. The sample was lastly washed with Chloroform (Merck) to separate fat and then analyzed by column chromatography (Zhao et al 2013; Xu et al 2019).

\section{Preparation of pellet feeds containing corn cob powder and Scillaren-A}

50 gram of $50 \%$ corn cob powder, 1 gram of 5.5\% Scillaren-A extract, and 49 gram of feed mixture (peanut butter, gluten, cornmeal, wheat flour, sunflower) were mixed to obtain the pellet. The 
mixture was processed through the pellet machine (Levent Makine) with sieves by forcing it to pass through the sieve by traveling on the weight. The high-speed mixer was run at 4000 rpm (Ujváry 2010).

\section{Analysis of Scillaren-A by LC-MS / MS}

Scillaren-A chemical detected by LC-MS / MS device in Akdeniz University Food Safety and Agricultural Research Centre was verified with NIST and Wiley libraries. LC-MS / MS System: Thermo Scientific Accela UHPLC- TSQ Quantum Access Max, Column: Hypersil GOLD RP C18 $(1.9 \mu \mathrm{m}), 50 \times 2.1 \mathrm{~mm}$, Column oven temperature: $40^{\circ} \mathrm{C}$, Injection volume: $5 \mu \mathrm{L}$, Capillary temperature: $270^{\circ} \mathrm{C}$, Evaporation temperature: $50^{\circ} \mathrm{C}$, Auxiliary gas pressure (Arb): 20, Sheath gas pressure (Arb): 50 , Spray Voltage (V): \pm 3500 (Bălăşoiu et al 2013; Yadav 2020).

\section{Experiment Protocol}

Approval for the study was granted by the Local Ethics Committee, Turkey. The experimental animals were fed and sheltered in the Laboratory Animal Unit of Hüseyin Aytemiz Experimental Research and Application Center, Kirikkale University. A total of 32 adult female rats, each weighing 300-350 $\mathrm{g}$, were kept in appropriate-sized cages at room temperature with $55 \%$ humidity, in a 12 -hour daynight cycle and they were fed ad-libitum with standard pellet feed. Before the intoxication, all group animals were starved for 24 hours. The rats were randomly divided into four groups. Each group included 8 rats. The Group I (G.I) animals was administered with $4 \mathrm{ml}$ Scillaren (Urginea (Scilla) Maritima (L.) extract) via gavage. The Group II (G.II) animals were fed with corn cob silkpowder $(25 \mathrm{~g}$ for each animal in the group) that was added to the pressed standard pellet and dissolved in $10 \mathrm{ml}$ corn oil. The Group III (G.II) animal was first administered with 4 $\mathrm{ml}$ Scillaren extract via gavage and corn cob powder (25 $\mathrm{g}$ for each animal in the group). The Group IV (G.IV) animals were selected as control and fed with a standard pellet. They were not intoxicated by any toxic substance. After 48 hours, all animals in every group were euthanized one by one within the euthanasia chamber. Each rat was sedated with xylazine (10 mg/kg BW, IM) and allowed 2 mins for acclimation of $100 \%$ carbon dioxide gas infusion.

\section{Postmortem examination}

The routine necropsy procedure was performed. Organs of all animals in each group were evaluated properly based on general macroscopical criteria of necropsy. The tissue samples (liver, kidney, lung, heart, central nervous system parts, spleen, and intestine) were fixed in $10 \%$ buffered formalin. The routine tissue process was followed up using an automatic tissue processor (Leica TP-1020) and tissues were embedded in paraffin (Shandon). Thereafter, paraffin blocks were cut at $5 \mu \mathrm{m}$ and stained accordingly to the hematoxylin-eosin (H\&E) staining procedure (Luna 1968).

\section{Histopathological examination}

The lesions were examined and scored in terms of hyperemia, hemorrhage, degeneration-necrose, and inflammatory cell infiltration.

\section{Results}

\section{Scillaren-A quantity analysis}

Urginea (Scilla) Maritima was extracted with ethyl alcohol containing $0.145 \mathrm{mg} / \mathrm{kg}$ amount of Scillaren-A.

\section{Necropsy findings}

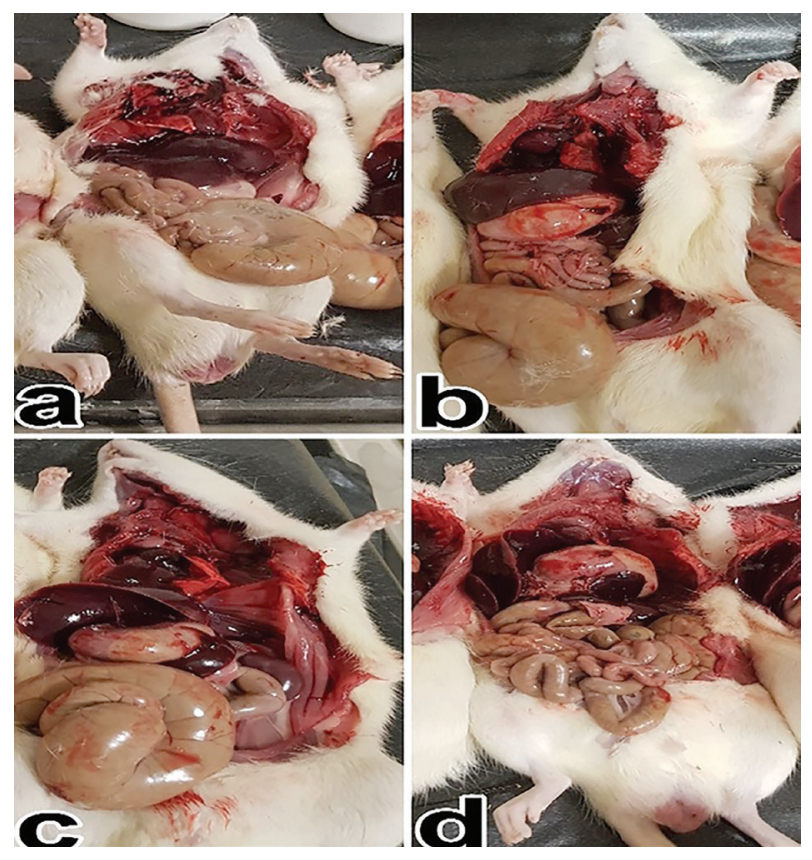

Figure 1. Macroscopical findings in experimental groups. (a) Group I animals, Scillaren extract via gavage, (b) Group II animals pressed powder of corn cob silk, (c) Group III animals, dough ball prepared from Scillaren extract and corn cob powder (d) Group IV animals, selected as control.

In G.I, the small intestine was hyperemic in appearance $(n=3)$. The large intestine was enlarged in a few animals $(n=3)$. The liver and spleen as well as lungs were congested $(n=4)$. The heart was stiffed in ap- 
pearance. The central nervous system was edematous and swollen. In G.II, the intestines and stomach were enlarged in two animals. In addition to the kidney, the liver and spleen were hyperemic and swollen as in the previous group. The heart and central nervous system were the same in appearance in all animals. In GIII, the large intestine was enlarged, the mucosa of the small intestine was hyperemic partly. The stomach was normal and filled with pellet contents. The liver and spleen were congested in a few cases. The lungs and kidneys were hyperemic. The hearts and central nervous system were edematous and swollen. In G.IV or control group, there were no meaningful pathological changes in organs (Figure 1).

\section{Histopathological results}

Liver: In G.I, the sinusoids were filled with erythrocytes and the central vein was enlarged. Some of the remark cords were dissociated $(n=4)$. There were many parenchymal degenerations in hepatocytes at the periphery of lobes $(n=6)$. The severe changes included both nuclei and cytoplasm of some hepatocytes. In G.II, the aforementioned findings with venous congestion were not common at each lobe of the animal $(n=5)$. In G.III, the congestion has spread to all lobules $(n=7)$. Additionally, there was neutrophil leucocyte infiltration in a few areas in the experimental group. In contrast to the experimental group, in G.IV, there was no meaningful finding.

Kidney: In G.I, the cortical tubules were lined with degenerated epithelial cells in some areas $(n=6)$. In G.II and G.III, the findings were such in case $(n=7)$. But, the distribution of degenerated areas was fewer compared to other groups in G.III. In addition, the capillaries were hyperemic in these groups $(n=8)$. In G.IV, there was no conspicuous finding.

Heart: In G.I, loss of striates, karyolytic changes as well as vascular changes related to parenchymal degenerations in cardiomyocytes were disseminated $(n=7)$. In G.II, these degenerative changes were observed focally in a few cardiomyocytes $(n=8)$, although they were present in G.III animals ( $n=7)$ as much as in $\mathrm{G} . \mathrm{I}$ animals. In G.IV, there was no pathological change.

Lungs: In G.I-II-III, the arterioles and interalveolar capillaries were filled and enlarged with erythrocytes as well as focal hemorrhagic foci ( $n=8$ approximately at each group). In some cases, in these groups $(n=5)$, edema was accompanied by hyperemia. In contrast to this, the vessels were normal in appearance in controls.

Spleen: In G.I and G.II, intrafollicular hemorrhage was observed disseminated $(n=6)$. But, in other groups including the control group animals, there were not any meaningful changes in the tissue. Additionally, follicle hyperplasia was seen in a few areas in groups $(n=3)$.

Intestine: In G.I and G.II, the capillaries were hyperemic in propria mucosa and submucosa $(n=7)$. In G.III, degenerative and necrotic changes were encountered in the crypt and apical parts of the villus epithelium of the intestine, and hyperemic changes in the previous group $(n=7)$. In G.IV, there were not any findings. Additionally, there were a few neutrophil leucocytes and lymphocytes infiltration in propria in some areas of experimental groups and control group animals.

Central Nervous System: In all groups, hippocampal neurons and Purkinje cells were degenerated or necrotic in appearance $(n=8$, approximately every group). However, such changes were fewer in G.III $(n=5)$. And also, no lesion except hyperemia was observed in the control group or G.IV.

The findings were illustrated in Figures 2 to 5 and Table 1.

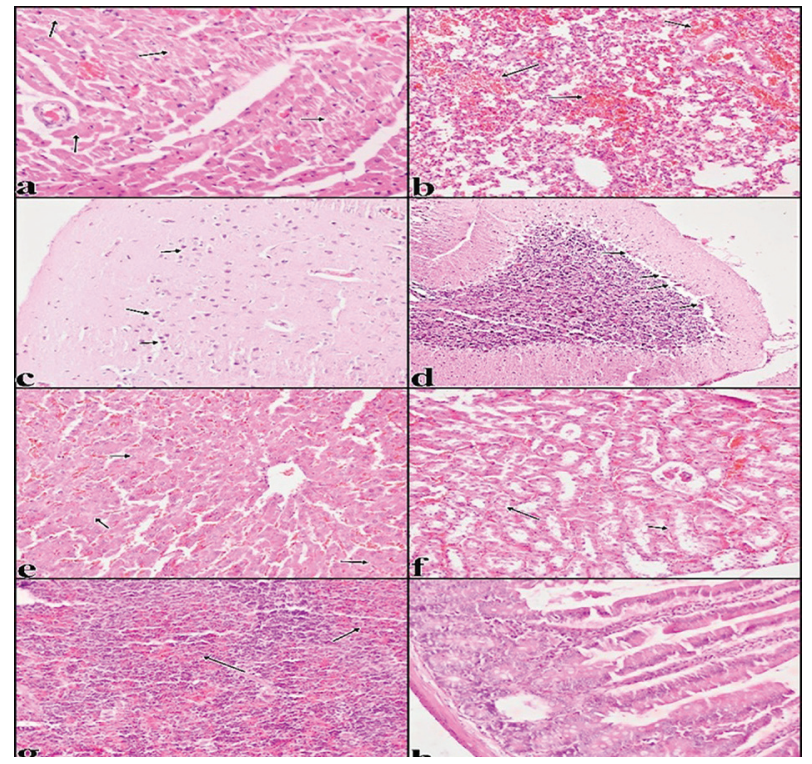

Figure 2. G.I. Focal hemorrhage, hyperemia, and degeneration-necrosis in cardiomyocytes. Degeneration and necrosis in the heart (a), focal haemorrhagia in the lung (b), degeneration and necrosis in Purkinje cell in the cerebellum (c), neuronal degeneration (d), degeneration in hepatocytes and hyperemia (e), hyperemia in the kidney $(f)$, normal in appearance of the spleen $(\mathrm{g})$, intestinal hyperemia (h), $\times 100$, Haematoxylin-Eosin staining. 


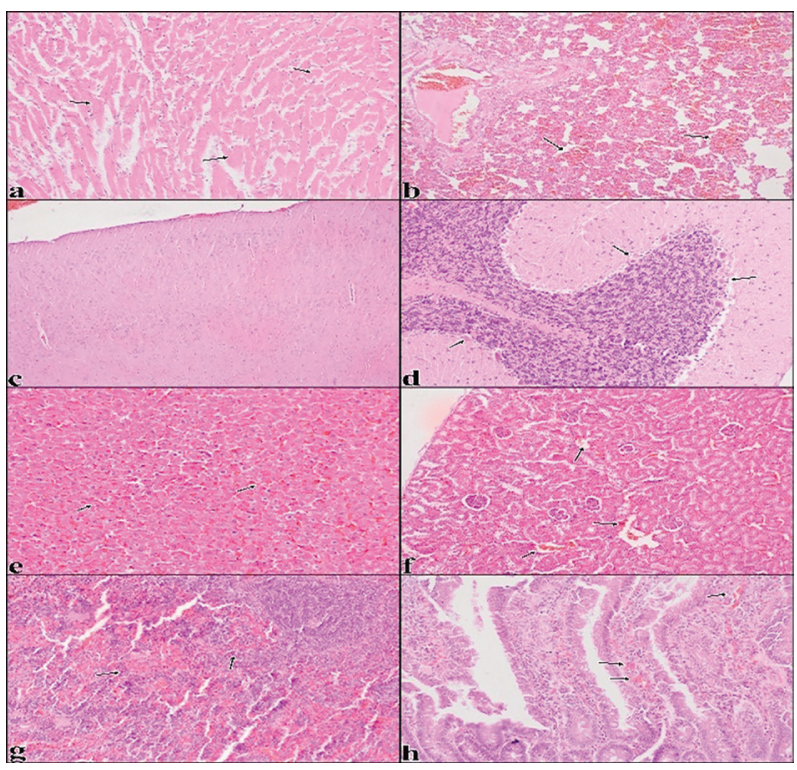

Figure 3. G.II. Disseminate hemorrhage, hyperemia, and degeneration and necrosis. Diffuse degeneration and necrosis in cardiomyocytes (a), diffusive hemorrhage and hyperemia in the lung (b), normal in appearance of the brain (c), degeneration and necrosis in the cerebellum (d), degeneration in hepatocyte and hyperemia in the liver (e), hyperemia in the kidney ( $f)$, diffuse hemorrhage in the spleen $(g)$, intestinal hyperemia $(h), \times 100$, Haematoxylin-Eosin staining.

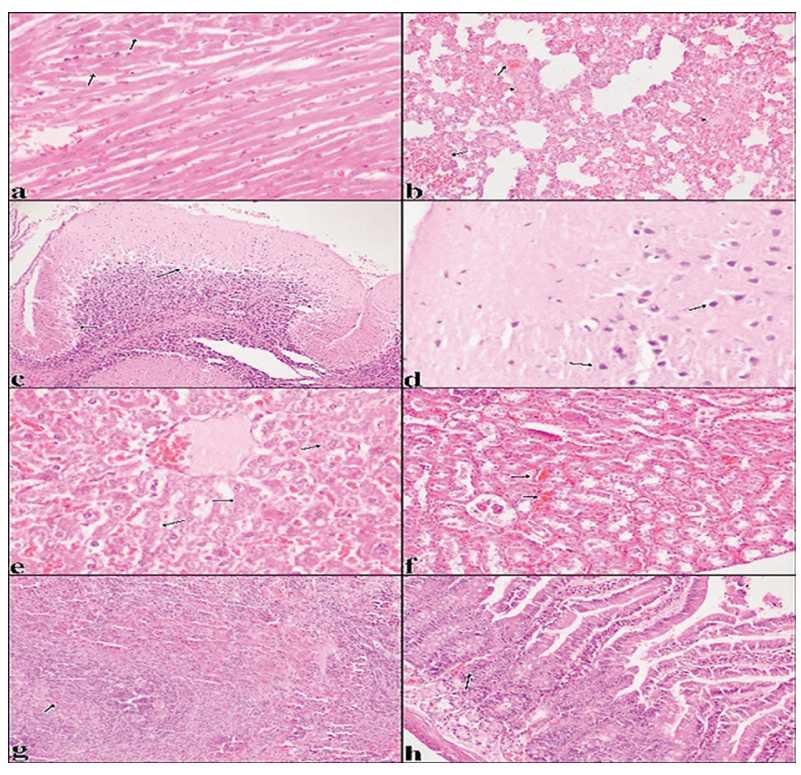

Figure 4. G.III. Disseminate hemorrhage, hyperemia, and degeneration and necrosis. Degeneration and necrosis in cardiomyocytes of almost all fields (a), diffusive hemorrhage and hyperemia in the lung (b), degeneration and necrosis in neurons of the ce- rebellum (c) and Purkinje cells of the cerebellum (d), degeneration in hepatocyte and hyperemia in the liver (e), severe hyperemia in the kidney ( $f$ ), diffuse hemorrhage in the spleen $(\mathrm{g})$, intestinal necrosis $(\mathrm{h})$, $\times 100$, Haematoxylin-Eosin staining.

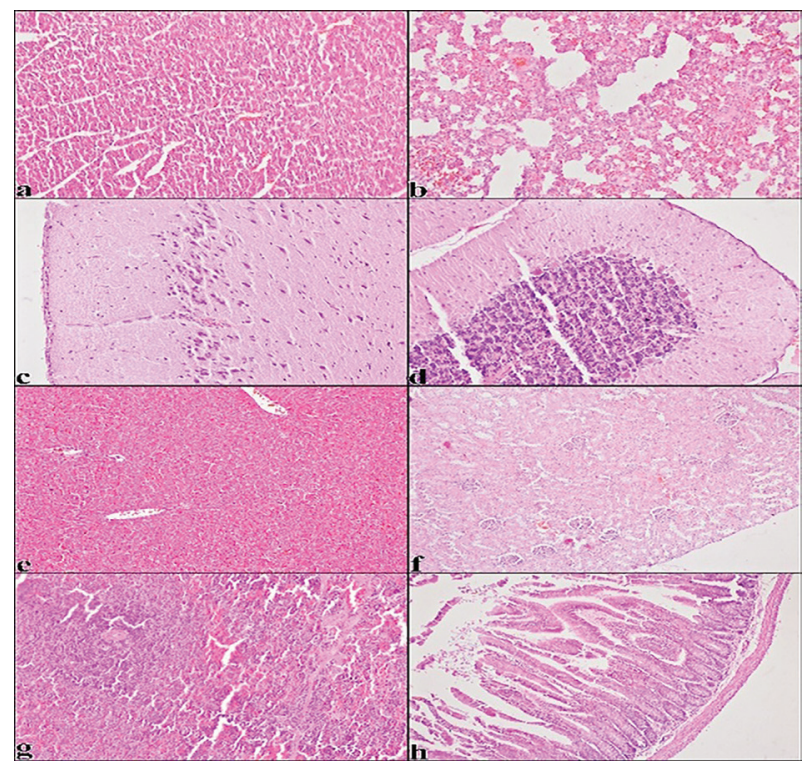

Figure 5. G.IV. No conspicuous pathological changes, heart (a), lung (b), cerebrum (c), cerebellum (d), liver (e), kidney (f), spleen (g), intestine (h), $\times 100$, Haematoxylin-Eosin staining. 
Table 1. Scoring of Histopathological Findings in Organs According to Experiment Groups.

\begin{tabular}{|c|c|c|c|c|c|c|}
\hline & Hyperemia & Haemorrhagie & $\begin{array}{c}\text { Degeneration- } \\
\text { necrosis }\end{array}$ & Inflammation & Hyplerplasia & Fibrosis \\
\hline \multirow{4}{*}{ Liver } & $+++\mathrm{G}(\mathrm{I})$ & $++(\mathrm{Gl})$ & $++G(I)$ & $-(\mathrm{Gl})$ & $-\mathrm{G}(\mathrm{I})$ & $-\mathrm{G}(\mathrm{I})$ \\
\hline & $++\mathrm{G}(\mathrm{II})$ & $++G(I I)$ & $++G(I I)$ & $-G(I I)$ & $-G(I I)$ & $-G(I I)$ \\
\hline & $+++G(I I I)$ & $+++G(I I I)$ & $+++G(I I I)$ & $-G(I I I)$ & $-G(I I I)$ & $-G(I I I)$ \\
\hline & $-G(I V)$ & $-\mathrm{G}(\mathrm{IV})$ & $-G(I V)$ & $-G(I V)$ & $-G(I V)$ & $-G(I V)$ \\
\hline \multirow{4}{*}{ Kidney } & $++G(I)$ & $+(\mathrm{Gl})$ & $++G(I)$ & $-(\mathrm{Gl})$ & $-G(I)$ & $-G(I)$ \\
\hline & $+++\mathrm{G}(\mathrm{II})$ & $++\mathrm{G}(\mathrm{II})$ & $+++\mathrm{G}(\mathrm{II})$ & $-G(I I)$ & $-G(I I)$ & $-G(I I)$ \\
\hline & $++\mathrm{G}(I I I)$ & $+++\mathrm{G}(\mathrm{III})$ & $++\mathrm{G}(\mathrm{III})$ & $-G(I I I)$ & $-G(I I I)$ & $-G(I I I)$ \\
\hline & $-\mathrm{G}(\mathrm{IV})$ & $-\mathrm{G}(\mathrm{IV})$ & $-G(I V)$ & $-G(I V)$ & $-\mathrm{G}(\mathrm{IV})$ & $-G(I V)$ \\
\hline \multirow{4}{*}{ Heart } & $++\mathrm{G}(\mathrm{I})$ & $+++(\mathrm{Gl})$ & $++\mathrm{G}(\mathrm{I})$ & $-G(I)$ & $-G(I)$ & $-G(I)$ \\
\hline & $+++\mathrm{G}(\mathrm{II})$ & $+++\mathrm{G}(\mathrm{II})$ & $+++\mathrm{G}(\mathrm{II})$ & $-G(I I)$ & $-G(I I)$ & $-G(I I)$ \\
\hline & $++\mathrm{G}(\mathrm{III})$ & $+++\mathrm{G}(\mathrm{III})$ & $++G(I I I)$ & $-G(I I I)$ & $-G(I I I)$ & $-G(I I I)$ \\
\hline & $-\mathrm{G}(\mathrm{IV})$ & - G(IV) & $-G(I V)$ & $-G(I V)$ & $-G(I V)$ & $-G(I V)$ \\
\hline \multirow{4}{*}{ Lungs } & $++\mathrm{G}(\mathrm{l})$ & $+(\mathrm{GI})$ & $+\mathrm{G}(\mathrm{I})$ & $-(G I)$ & $-G(I)$ & $-G(I)$ \\
\hline & $++G(I I)$ & $+G(I I)$ & $+\mathrm{G}(\mathrm{II})$ & $-G(I I)$ & $-G(I I)$ & $-G(I I)$ \\
\hline & $+++G(I I I)$ & $++\mathrm{G}(\mathrm{III})$ & $+\mathrm{G}(\mathrm{III})$ & $-G(I I I)$ & $-G(I I I)$ & $-G(I I I)$ \\
\hline & $-\mathrm{G}(\mathrm{IV})$ & $-\mathrm{G}(\mathrm{IV})$ & $-G(I V)$ & $-G(I V)$ & $-G(I V)$ & $-G(I V)$ \\
\hline \multirow{4}{*}{ Spleen } & $++G(I)$ & $++(\mathrm{GI})$ & $++G(I)$ & $-(\mathrm{GI})$ & $-G(I)$ & $-G(I)$ \\
\hline & $+++\mathrm{G}(\mathrm{II})$ & $+\mathrm{G}(\mathrm{II})$ & $+++G(I I)$ & $-G(I I)$ & $-G(I I)$ & $-G(I I)$ \\
\hline & $++G(I I I)$ & $++\mathrm{G}(\mathrm{III})$ & $++\mathrm{G}(\mathrm{III})$ & $-G(I I I)$ & $-G(I I I)$ & $-G(I I I)$ \\
\hline & $-\mathrm{G}(\mathrm{IV})$ & $-\mathrm{G}(\mathrm{IV})$ & $-\mathrm{G}(\mathrm{IV})$ & $-G(I V)$ & $-G(I V)$ & $-G(I V)$ \\
\hline \multirow{4}{*}{ Intestine } & $++\mathrm{G}(\mathrm{I})$ & $-(G I)$ & $++G(I)$ & $-(G I)$ & $-G(I)$ & $-G(I)$ \\
\hline & $+++\mathrm{G}(\mathrm{II})$ & $-G(I I)$ & $+++\mathrm{G}(\mathrm{II})$ & $-G(I I)$ & $-G(I I)$ & $-G(I I)$ \\
\hline & $++\mathrm{G}(\mathrm{III})$ & $-G(I I I)$ & $++\mathrm{G}(\mathrm{III})$ & $-G(I I I)$ & $-G(I I I)$ & $-G(I I I)$ \\
\hline & - G(IV) & - G(IV) & $-G(I V)$ & $-G(I V)$ & $-G(I V)$ & $-G(I V)$ \\
\hline \multirow{4}{*}{$\begin{array}{l}\text { Central } \\
\text { Nervous } \\
\text { System }\end{array}$} & $++G(I)$ & $-(\mathrm{GI})$ & $++\mathrm{G}(\mathrm{I})$ & $-(\mathrm{Gl})$ & $-G(I)$ & $-G(I)$ \\
\hline & $+++G(I I)$ & $-G(I I)$ & $+++\mathrm{G}(\mathrm{II})$ & $-G(I I)$ & $-G(I I)$ & $-G(I I)$ \\
\hline & $++G(I I I)$ & $-G(I I I)$ & $+++\mathrm{G}(\mathrm{III})$ & $-G(I I I)$ & $-G(I I I)$ & $-G(I I I)$ \\
\hline & $+\mathrm{G}(\mathrm{IV})$ & $-G(I V)$ & $-G(I V)$ & $-G(I V)$ & $-G(I V)$ & $-G(I V)$ \\
\hline
\end{tabular}

\section{Discussion}

In this study, a more effective rodenticide was developed by joining the structure of the corn cob powder of the active ingredient of Scillaren-A, which participates in the heterosite structures of the Urginae Maritima (L.) plant that is nationally and naturally grown for rodenticide use. The results obtained with this study are original for the usage of two different rodenticides together. This double rodenticide usage was seen to provide a multiple organ failure when compared to the sole usage of each rodenticide. In particular, it was encountered with these destructive effects in some of the vital organs such as the liver, kidney, and heart.
Corn cob powder is normally used for rats (Rattus norvegicus) at doses of $50-100 \mathrm{mg} / \mathrm{kg}$. In most cases, corn cob powder is not efficient due to high dose requirement, therefore a more effective organic method is required. The addition of Scillaren-A to the rodent substance is important for improving combat effectiveness in this sense.

On the other side, Urginea Maritima (L.), or squill plant grows on sandy, rocky, and stony areas. Urginea Maritima, with an average weight of up to 2.5 $\mathrm{kg}$, has been reported to have an active ingredient ratio of $0.4 \%$ to $0.5 \%$ (Verbiscar 1986b). This means that approximately $12-13 \mathrm{~g}$ of active ingredient can be extracted from an adult onion plant. This value means approximately 500-700 Rattus norvegicus deaths in intravenous use (Brooks and Htun 1980). 
It is aimed to lower the active substance dose to be given to mice/rats orally compared to the currently used rodenticides. On the other hand, it is known that many active substances used as pesticides today may also have a repellent effect on living creatures. In addition, it is seen that long-term use of pesticides causes resistance between generations. In Rattus norvegicus, the central olfactory unit can adapt to different odorents. In this study, it was observed that the mixture prepared with Scillaren-A and pure corn cob powder did not show any repellent effect and was consumed with great appetite. With ByPass Proteins, which will be included in the rodenticide structure, the livings'/alive death that occurs between a few hours and 2 days under normal conditions will be extended to a period of 2-10 days. By this, the death of the animal in the places such as granary, field, or home interiors where the direct application is made will be prevented at the maximum level.

Among the histopathological changes in this group of animals, the presence of more severe and widespread bleeding, widespread necrosis and degenerations in cells in the heart muscle, edema related to general circulatory failure, and hyperemia have been observed. In addition, more common necrotic changes have been observed in the intestines of several animals and it has been concluded that this may be documented for toxicity. As a general picture, it was observed that the findings were similar to the corn-cob silk formulation and gave close results to the commercial formulation.

\section{Conclusion}

Different degrees of lesions were formed in the organs of all intoxicated groups. It is understood from the rapid development of deaths that the most severe findings were obtained with a ready-made commercial formulation. However, the administration of powder of corn cob powder and scillaren, which has a stronger effect than the corn corb silk formulation, seems to cause widespread damage to the organs. It was noticed that although organ damage occurred in the mentioned regions, it was mainly effective in hepatocytes, kidney tubules, and the heart muscle. Therefore, the disorder in the general circulation fails in the liver and kidney functions. Also, it causes slow death in the other affected organs such as the lung and brain. Both rodenticide formulations can create a more harmful effect in multiple organs at the same period. For this reason, by combining different aromatic properties and adding attractive odor and taste additives, both rodenticides might be an effective formulation after careful calculations to increase the relative amount of scillaren extract and to maintain the amount of toxic substance per animal.

Acknowledgment: This research study is original and is not submitted anywhere as full text or abstract. And, the authors have no conflict of interest with any researchers.

Ethics Committe: This study was carried out with the permission of the Kirikkale University Animal Experiments Local Ethics Committee, Kirikkale, Turkey (Decision No: 06.11.2019-2019/12-57) report.

Funding: The research work was supported by grants of the KOSGEB Project.

\section{References}

Aktaş İ, Özmen Ö, Tutun H, Yalçın A, Türk A. (2020) Artemisinin attenuates doxorubicin induced cardiotoxicity and hepatotoxicity in rats. Biotech Histochem. 95,121-128. doi: 10.1080/10520295.2019.1647457

Alp H, Tutun H, Kaplan HM, Şingirik E, Altintaş L. (2019) Investigation of apoptotic effects of hypericum perforatum extract on breast cancer cell line. Harran Üniv Vet Fak Derg 8, 198-202. doi: 10.31196/huvfd.667748

Bălăşoiu L, Călina D, Docea A, Patru E, Valse E, Maria B. (2013) Determination of cardiac glycosides in Scilla bifolia (Liliaceae) by two different analytical techniques: Thin Layer Chromatography (TLC) and High Performance Liquid Chromatography-Mass Spectrometry (HPLC-MS). J Med Plants Res. 7, 3131-3138. doi:10.3906/zoo-1611-32

Bayazıt V, Konar V. (2010) Analgesic effects of scilliroside, proscillaridin-a and taxifolin from squill bulb (Urginea maritima) on pains. Digest I Nanomaterial Biostruct. 5, 465-467.

Bilir EK, Tutun H, Sevin S, Kismali G, Yarsan E. (2018) Cytotoxic effects of Rhododendron ponticum L. extract on prostate carcinoma and adenocarcinoma cell line (DU145, PC3). Kafkas Üniv Vet Fak Derg. 24, 451-457. doi: 10.9775/ kvfd.2017.19219

Brooks JE, Htun PT. (1980) Laboratory evaluation of scilliroside used as a rodenticide against the lesser bandicoot rat, Bandicota bengalensis. J Hygiene. 85,227-234. doi:10.1017/S0022172400063269.

Gentry HS, Verbiscar AJ, Banigan TF. (1987) Red squill (Urginea maritima, Liliaceae). Economic Botany. 41, 267-282. doi: 10.1007/BF02858974

Gratz NG. (1973) A critical review of currently used singledose rodenticides. Bull WHO. 48, 469-477.

Gupta RC. (2018) Non-Anticoagulant Rodenticides. Gupta RC eds. Veterinary Toxicology. Third edition. USA: Academic Press; p. 613-626.

Jacob J, Buckle A. (2018) Use of anticoagulant rodenticides in different applications around the world. Anticoagulant 
Rodenticides and Wildlife. Springer, Cham.USA p. 11-43. doi: 10.1007/978-3-319-64377-9_2

Kasote DM, Katyare SS, Hegde MV, Bae H. (2015) Significance of antioxidant potential of plants and its relevance to therapeutic applications. Int J Biol Sci. 11, 982. doi: 10.7150/ijbs. 12096

Keyvan E, Tutun H. (2019) Effects of carvacrol on Staphyloccus aureus isolated from bulk tank milk. Medycyna Weterynaryjna-Vet Med Sci Pract. 75, 238-241. doi: 10.21521/mw.6211

Luna LG. (1968) Manual of histologic staining methods of the armed forces institute of pathology. Third edition. New York USA: McGrawHill.

Mahlo SM, Chauke HR, McGaw L, Eloff J. (2016) Antioxidant and antifungal activity of selected medicinal plant extracts against phytopathogenic fungi. Afr J Tradit Complement Altern Med. 13, 216-222. doi: 10.21010/ajtcam.v13i4.28

Perry SC. (2013) U.S. Patent No. 8,574,638. Washington, DC: U.S. Patent and Trademark Office. 2013.

Sikarwar MS, Patil MB. (2014) Antihyperlipidemic activity of Pongamia pinnata leaf extracts. Turk J Pharmaceut Sci. 11, 329-338.

Tanker M, Tosun F. (1979) Ege yöresinde yetişen Urginea maritima (L.) Bak. soğanlarının Prosillaridin yönünden değerlendirilmesi: Evaluation of the Balbs of Urginea maritima (L.) Bak. Growing in the Aegean District from. $J$ Facult Pharm Ankara Univ. 9, 1-11.

The Pesticide Manual. (1983) Worthing CR, Walker SB. eds. A World Compendium. Seventh edition. British Crop Protection Council, England: Croydon; p. 697.
Tobyn G, Denham A, Whitelegg M. (2010) The western herbal tradition: 2000 years of medicinal plant knowledge. Singing Dragon, UK: Churchill Livingstone; p. 1-392. doi:10.1016/B978-0-443-10344-5.00020-3

Tutun H, Koç N, Kart A. (2018) Plant essential oils used against some bee diseases. Turkish J Agricult-Food Sci Tech. 6, 3445. doi: 10.24925/turjaf.v6i1.34-45.1502

Ujváry I. (2010) Pest control agents from natural products. Kriger R. eds. Hayes' Handbook of Pesticide Toxicology. USA: Academic Press; p. 119-229. doi: 10.1016/B978-012-374367-1.00003-3

Verbiscar AJ, Patel J, Banigan TF, Schatz RA (1986a). Scilliroside and other scilla compounds in red squill. J Agricult Food Chem. 34, 973-979. doi: 10.1021/jf00072a011

Verbiscar AJ, Banigan TF, Gentry HS. (1986b) Recent research on red squill as a rodenticide. Salmon TP. eds. Proceedings of the 25th Vertebrate Pest Conference. University of California, USA: Davis; p. 51-56.

Xu S, Wang G, Guo R, Zhang J. 2019. Extraction of steviol glycosides from Stevia rebaudiana (Bertoni) leaves by high-speed shear homogenization extraction. J Food Proc Preserv. 43(12), e14250. doi: 10.1111/jfpp.14250

Yadav PB, Lekhak UM, Ghane SG, Lekhak MM. (2020) Phytochemicals, antioxidants, estimation of cardiac glycoside (Scillaren A) and detection of major metabolites using LC-MS from Drimia species. South African J Botany. doi: 10.1016/j.sajb.2020.05.002

Zhao J, Zhang W, Zhang X, Zhang X, Lu C, Deng Y. (2013) Extraction of cellulose nanofibrils from dry softwood pulp using high shear homogenization. Carbonhydr Polymer. 97: 695-702. doi: 10.1016/j.carbpol.2013.05.050 